\title{
SOCIO-RELIGIOUS MOVEMENT OF RELIGIOUS AFFILIATED STUDENT ORGANIZATIONS AFTER SOCIAL CONFLICT IN AMBON
}

\author{
Yance Zadrak Rumahuru \\ Sekolah Tinggi Agama Kristen Protestan Negeri Ambon \\ Email: rumahuru@yahoo.com
}

\begin{abstract}
This article examines student social movements with a focus of student activities in extra-campus organizations, especially the Islamic Students Association (HMI) and the Indonesian Christian Students' Movement (GMKI) at the campus of the Pattimura University, State College of Islamic Studies Of Ambon and the State College of Protestant Christian Studies Ambon, which aims to describe forms of student social movements in responding to social issues and development in the city of Ambon and Maluku after the conflict. The data of this study were collected using a qualitative method approach through observation, interviews and document study. Therefore, this study is qualitative, the data were analyzed qualitatively and presented descriptively. This study found that first, cadres or members of HMI and GMKI always strive to master public spaces on campus through the distribution of their cadres to occupy strategic positions in the executive bodies or the student senate, even the seniors who have become lecturers in structural positions on campus, which in turn can affect campus policies. Second, the activities in the movement of HMI and GMKI have similarities in terms of responding to social issues, by paying attention to a few aspects including socio-religious issues, local political issues and post-conflict community development.
\end{abstract}

Keywords: Student Social movements, HMI, GMKI, Campus, Identity

\section{INTRODUCTION}

In the history of many nations, students always pioneer various movements that lead to the changes in society. In the Indonesian context, several important events were led by students, such as (1) May 20, 1908, when students and youth united against the colonists, and became the awakening moment of students, youth and community groups that are now the Indonesian people to free themselves of colonialism. This event became known as the National Awakening Day. (2) October 28, 1928 student organizations and youth pioneered the oath of youth. (3) the events were still fresh in Indonesian people's 
mind which was May 21, 1998, when students brought down the second president of the Republic of Indonesia, General Suharto from power, and is an important moment for the development of better democracy in this country. This event became known as the era of reform, which inspired the entire governance and organization of the state to this day.

Along with the discussionaboutstudent social movementsin Indonesia, both nationally and regionally, two student organizations, namely the Islamic Students Association (HMI) and the Indonesian Christian Students' Movement (GMKI) can be said to be a representation of a social movement among students which is an interesting topic to study. It is known that both student organizations have a long historical background along with the existence of the Republic of Indonesia.

The focus of this study is the student social movement in the city of Ambon regarding the activities of off-campus organizations, in this case the HMI and GMKI. Therefore, this study was carried out at the Muslim Students' Association at the Pattimura University and State Institute of Islamic Studies at Ambon and the Indonesian Christian Students' Movement at the Pattimura University and the College of Christian Religious Studies at Ambon. The issues to be discussed in this article are the kinds of social movement activities of the students in responding to issues of community development in post-conflict in Ambon and Maluku in general in the last 15 years.

Research on the social movements of students in Ambon City can be seen as part of a study of social movements in Indonesia in general, and is important because after the 1998 reform, which had implications for the fall of the New Order Regime, there is a tendency of strengthening social movement activities at a number of campuses in different regions. In the context of the city of Ambon and Maluku overall, student movements have gained a strong hold since 1998 in line with the overall student movements in Indoneisa to bring down Suharto, and further strengthened during the conflict of 1999. The phenomenon of student social movements in Ambon City experienced post-conflict changes, the more leading to religious movements that have been growing at the campus and many feared that they may have negative impacts on campus activities and the community at large.

Youssef M. Choueri (1997), who studied Islam as religious movements found that the phenomena of religious movements become a development which he calls the revivalism, reformism, and radicalism. 
Each term is a separate entity and has a historical background, socioeconomic and conceptual framework of its own. In line with this study, Flavius Floris Andries (2012), examined the Campus mosque movements at UGM and UIN Sunan Kalijaga in the understanding of national politics, and found that religious movements that emerged in the campus is a response to the social dynamics that swept the nation. Takmir masjid is one of the forms of religious movements that emerged at UGM and UIN Sunan Kalijaga, with different goals and missions between the two campuses. The difference is largely determined by the theological views held by each of these movements. In this research, it has clear differences in theological opinion between the two campuses in understanding political issues. For religious movements at the mosque of UIN Sunan Kalijaga, discussing political issues is part of the responsibilities of the campus mosque, while the movement of the UGM, political issues are outside the responsibility of the campus mosque.

With regard to the reality in the city of Ambon, it is expected that this study is an attempt to map out the forms and activities of student social movements in the city of Ambon and explain how social and religious movements affect the activities of college students and the community in Maluku. Said Ernas (2016) gives a background of the curent situation of architecture of peace in Ambon that is related to the social movement studies by this work. This study is expected to add a reference about social movements and religious movements, particularly among students in Indonesia. The results of this study are also expected to be input for colleges and universities, government and other institutions in formulating policies that benefit students in ethnically and religiously diverse communities.

The discussion in this study uses the theory of social movements, so it will put forward the concept of social movements. Giddens (1993) argued that social movements are an attempt collectivity to pursue a common interest, or movements to achieve common goals through collective action outside the established scope of institutions. Unlike Gidens, Robert Mirsel (in Berger, 2004) observed that social movements are not merely studying the collective actions that are not only institutionalized as in the classical studies, but also shifted the movements toward being organized and institutionalized not merely spontaneous movements. Religious movements in the world of colleges can be categorized as a social movement, which aims to show 
and maintain religious identity among both Christians and Muslims as a filter for the community. Therefore, a social movement aims to promote a change in values and norms in society in order to manifest a purification (Peter Berger, 2004: 325).

To undertake the study of social movements, the role of actors or individuals occupies a very important position, because it is essentially a social movement which is a collection of individuals. Ignoring the fact that the a social movement is made up of people will be at risk of treating it as single empirical data. The fact that those individuals acting together need to be explained and should not be considered as something that just happens (Rumahuru, 2013). In other words, it should be noted that social movements are more than just a single phenomenon, because only on the level of analysis of individual can it be explained why some people are involved to participate in a certain social action and not another. By using this view, then we will be able to collect individual resources, such as self ideology, the values of subjectivity, opinions or individual perspectives, the actor's motives, actor's purpose, the subjective meaning of the actor, the reality around them, etc.

Specifically regarding social movements associated with the religious movement itself, there appeared various terms used by scholars to describe religious movements. Tibi (1998), Azra (1996), Choueri (1997), Burrell (1995) and Karyono, (2003) used the term fundamentalism. In addition, for Indonesian case, Burhanuddin (2016) gives an explanation of the root of the term of fundamentalism. And Sivan (1985), Roy (2005) and Turmudi, et al. (2005) like to use the term radical. The issue is a complex movement that sometimes stops at the level of labeling. However, labeling does not bring a better understanding. Each movement has its own background, because its birth cannot escape from the religious, economic, social, cultural and political influence. Zaenuddin Hudi Prasojo (2016), for example, argues that some aspects including ethnicity and religion can also give influences to movement and social identity. The orientation of these movements depends on which aspects are the most prevalent among the factors above.

\section{GENERAL CONTEXT OF STUDENT SOCIAL MOVEMENTS IN AMBON}

Ambon city as the center of the province of Maluku, and an educational center, has become an arena of growing religious movements which started from college 
students. Therefore, this study focuses on the student religious movements on campus, where two student organizations become representational activities of religious movements in Ambon i.e., the Islamic Students' Association (HMI) and the Indonesian Christian Students' Movement (GMKI), respectively at the Pattimura University (UNPATTI), State Institute of Islamic Studies (IAIN) Ambon and the State College of Christian Religious Studies (STAKPN) Ambon. Unpati is a national campus categorized as a large secular campus in the city of Ambon and Maluku, while IAIN is categorized as a campus with Islamic religious background, and STAKPN Ambon categorized as a campus with Christian religious background.

With regard to socio-religious movements of HMI and GMKI, both have a long history, and their activities can be seen from their existence in the New Order era to the era of reform. In each period, both organizations had experience of history and dynamics of relations with different countries. However, HMI and GMKI and their movement activities have militancy and continuity of movement that never diminished or extinguished in guarding every government policy and polices within the campus. Although HMI and GMKI are partners labeled as campus religious organizations, their socioreligious movements emerged in the form of social activities.

Regarding militancy and continuity of religious social movements, both HMI and GMKI have close links with activists involved in the movement. Therefore, aspects of the formation and regeneration as expansion and an increased number of mass is a major factor in driving the sustainable existence of the organization as well as their entire agendas. Formation and regeneration are an important and strategic factor because the campus is an intellectual or academic community with well-educated people, and actors involved in the organization have an important role in developing the mission of the movement both within internal campus and in the community.

Since the beginning of HMI and GMKI's presence on campus, the two organizations are a strategic means to carry out the regeneration and development of activists. It is understandable that students as educated people would have legitimacy in a movement compared to other social groups who are not educated. Therefore, HMI and GMKI positioning themselves as partners of the campus is an important thing. This study found that as campus partner organizations, cadres or members of HMI and GMKI ensure that they can occupy strategic positions in the executive branch or the student government body which in turn can affect campus policies. 


\section{FORMS OF STUDENT SOCIAL MOVEMENTS IN AMBON CITY}

Students as a college community are always identical to the designation of future generations, so it is often found that colleges have organizations that pay attention to the development of character, and leadership cadre. Concrete examples of such organizations are HMI and GMKI. The presence of such student organizations, besides carrying the issue of nationalism, also pay attention to religious issues, because it cannot be denied that social and religious background is important in the presence of these organizations. Therefore, the activities of GMKI and HMI cannot be separated from socio-religious aspects in a society that starts from the campus. Student activities on campus as a religious social movement serve as a process of self preparation from the campus to get involved in every process of development through contribution of thought to be critical of any policy for the advancement of the nation. The available space is for the formation of self-awareness, understanding, skills and abilities of students on campus, resulting in many people from outside the campus to be able to take advantage of student attendance as a new intellectual community to encourage the ideals of social groups outside the campus.

It is known that the HMI is an organization of cadres among students at the national level, therefore the HMI at the campus IAIN Unpatti Ambon has the same goals as the HMI at other universities. The main goals of the HMI are to prepare academic people, devotees and creators with Islamic spirit; and to create a fair and prosperous society with the grace of Allah. Implementation of these objectives by each cadre of HMI is by improving academic skills of the members and specific skills that help its cadres to be able to compete on campus and off campus. The HMI as a student organization with an Islamic background also instills spiritual doctrine, where the implementation can be seen in various activities of religious-oriented social movements in two aspects including uluhiyah (belief) and Ubudiyah (social worship).

Like HMI, GMKI is also a national level student organization aimed at the development of intellectual abilities and character, with the goal of coaching students not only intellectually but also to have leadership skills based on Christian values. The GMKI in the socio-religious movement has three principles of science, faith and devotion. Tripanji or three pillars can be explained as follows: the cadres of GMKI should be intellectually powerful, master of science and technology, and having unwavering faith. Through science and technology capabilities, GMKI cadres will be able to perform community or church service. Dedication to the community or the church on one side is the actualization of the GMKI tripanji, in addition, it indicates the existence of GMKI as: church incognito "which is doing service to all 
denominations and to society in general.

The existence of HMI and GMKI has stood the passing of time and has a long history with various dynamics of the organization, especially in relation with the State, with varying dynamics since the New Order era to the current reform era. HMI and GMKI movement activities have militancy and continuity of that never diminished or extinguished in guarding the government's policies, as well as internal affairs on campus. HMI and GMKI are both partner organizations labeled campus religious, with religious social movements emerged in the form of social activities. Militancy and continuity of religious social movements both HMI and GMKI have close links with activists involved in the movement. Therefore, the aspects of the formation and regeneration as expansion and an increased number of mass base are a major factor in driving the sustainable existence of the organizations. Formation and regeneration are an important and strategic factor because the campus is a place where educated actors are involved in the organization, have an important role in developing the mission of the movement both internally and externally, or in the community outside the campus.

Since the beginning, HMI and GMKI presence on campus is a strategic means to carry out the regeneration and the formation of activist movements. The existence HMI and GMKI despite having Muslim and Christian religious background, their movements are beyond the boundaries of religious, social aspects in each community without looking at the background of ethnicity, religion, and region. It is an attitude of openness practiced by HMI and GMKI as a cadre organization, which since its inception is very sensitive and concerned with social issues.

\section{SOCIAL ISSUES AS STUDENT MOVEMENT FOCUS Religious Discourse}

Referring to the goals of HMI which are to prepare academic people, devotees and creators with Islamic spirit; and to create a fair and prosperous society with the grace of Allah, then religious discourse becomes an important thing discussed at the HMI. The religious discourse discussed in the context of the HMI in Ambon and IAIN Unpatti at the macro level is associated with the cultivation of human values, human rights, justice and honesty. Internally, such religious discourse associated with the various activities of the organization is based on two fundamental aspects of the faith as a Muslim i.e. aspects of uluhiyah and ubudiyah. The aspect of uluhiyah is knowledge of God as the command in the Quran, Allah says "keep your duty to Allah and 
help each other to virtues and prevent vice". The aspect of uluhiyah is associated with the duties of every individual given by Allah to obey His command that appears in worship (rituals). Uluhiyah aspects of the daily activities of each individual in its implementation as the Qur'an commands, is for example, when the prayer has been concluded, disperse within the land and seek from the bounty of Allah (social worship).

Implementation of the uluhiyah concept in the context of HMI arises in the celebration of Islamic holy days, spiritual sermons, Friday prayers even though it is the consciousness of every individual Muslim, it remains a concern for HMI. Implementation of the concept $u b u$ diyah in social reality appears in forms of social relations, for an example HMI has good relations with GMKI and the cadres are actively involved with youth organizations such as KNPI, as a medium to carry out social worship, a place for sharing and discussion to find solutions on how to build a paradigm among different communities. On the other hand, through the social relations, HMI can perform a variety of social worship addressing various social problems in society, thinking critically about any social change in society and take concrete actions as the solution.

Religious discourse discussed at the HMI is not only related to the issue of theological doctrine but also includes social issues as the implementation of Islamic values in totality in the community. Implementation of Islamic values is a fundamental issue and of serious concern for HMI at the Unpatti on grounds that the question of faith associated with the theological and dogmatic values are personal matters and the responsibility of the individual, therefore, HMI does not preach on campus. Similarly, the affairs of religious rituals like Friday prayer, or anything else that is ritual, is considered a private matter and not a matter of the organization because it is a matter of concern for the mosque takmir in Campus which organizationally has no hierarchical relations with the organization of HMI.

The importance of the implementation of Islamic values of peace is the values of Islamic theology discussed in the context of the HMI at Unpatti and IAIN Ambon. In fact, the people of Maluku over all are traumatized by the conflict, experiences of conflict with all forms of action and violence in the collective memory of the people of Maluku that shape new bigotry, resentment, and hatred among the citizens of the Muslim and Christian communities. In this context, HMI views that religious discourse is inappropriate to question the contribution 
of religion to social issues that are rife with corruption, poverty, terrorism which are always associated with Islam. So Islam being not a religion of peace but a terrorist religion by society, and the fact that media always bring news of violent acts in the name of religion and the events terrorist will legitimize the thesis of Gregory Baum, who said that "religion is ambiguity" (Baum, 2001) and Appleby (2000) who said that religion is ambivalent.

In accordance with GMKI motto, Ut Omnes Unum Sins which means that all to be one, then, the religious aspect remains one of the important part of the discourse and discussed at GMKI. The GMKI at at Unpatti and STAKPN Ambon has a regular agenda to discuss religious issues through regular worship. Like HMI, regarding the religious discourse, GMKI has more discussions and studies of the Bible focusing on social issues, for example the problems of poverty, environmental crisis, cultural crisis, the crisis of education, etc.

In this light, it appears that religious discourse discussed in the context of GMKI has shifted from the discourse of dogmatic theology toward praxis. GMKI as an intellectual community with Christian identity within the meaning of religion being more directed at social aspects of a shared reality. It needs to be viewed in this context regarding the attitude of GMKI in view of issues of injustice in churches and church internal bureaucratic problems. It seems that GMKI does not give special attention to discuss the issues of the church in the way they discuss social, economic, political, cultural issues of the community hit by the impact of government policies that are not in favor of the community. This is because GMKI position itself as the Church in terms of incognito church, so GMKI directly involves itself in solving problems that afflict people without criticism of the church as if it did not care about the people but persisted in building the solid walls of bureaucracy.

\section{LOCAL POLITICAL DISCOURSE Regional autonomy}

The issues of regional autonomy received attention from both HMI and GMKI in Ambon City. HMI and GMKI in the city of Ambon view that regional autonomy as the implementation of a decentralized system will ultimately lead to new problems where there is land domination and the emergence of warlords. In this case, local autonomy does not resolve a number of problems in the area, but instead creates new issues. Creation of new districts does 
not reduce poverty but opens new opportunities for political infidelity and corruption as a form of abuse of power. On the other hand, peoples' rights are eroded or displaced and taken over by the center and those who possess capital. In other words, decentralization does not provide protection for the rights of indigenous peoples of their ancestral lands because of the reality is that customary lands have been used as an arena of contestation in this case by both central and local governments and capitalist groups. The consequence is that society as customary rights of land owners are becoming victims because their limited resources make it difficult for them to process the matter legally. Clearly we can see this case in Buru island and on the island of Seram. In two large islands in Maluku, with the expansion of a dispute of land owned by the community because there are mines as the source of many people's interests as well as the source of power contestation arena where capital and social capital are contested.

\section{Election}

Changes in the political system of the democratic stage in the post-New Order era in Indonesia are among others the introduction to direct elections of the president, governors, mayors and regents, as well as legislative members. In other words, the changes in the political system of post-New Order no longer adhere to the representative system but through participatory system. The applicability of the participatory system on the one hand is good, because every member of the society has the opportunity to freely use their right to vote for their representative by anyone or any political party. In this context, every individual has the freedom to choose so that the life of democracy is increasingly better.

In contrast with the expectation that each individual has the freedom to choose, public awareness about the importance of democracy education is not properly implemented. Therefore, the democratic process through legislative elections is loaded with political transactions, where money, family, ethnicity have become a campaign tool as a strategy to gain power as the main objective so that the democratic process is not healthy anymore. This phenomenon when using Bourdieu argument about the arena, then it is a strategy, because for Bourdieu it is not possible for actors to be present in the void when entering the arena of contestation (Bourdieu, 1977). Money, family, ethnicity are economic, social and cultural networks (Bourdieu, 1977) that can be observed and seen as forms of relations that can help the actors in the struggle for power. In this context, a healthy democratic process or a clean and honest way is not a goal, but the expectation to be successful as a winner is the 
actors' objective. Therefore, various methods and strategies are used to run elections although their impact is not democratic, legally flawed, etc.

\section{Security and Peace Building Discourse}

The Maluku conflict that took place from 1999 to 2004 left a long trauma for the people of Maluku. Psychological conditions of Maluku have yet to be safe for both communities. Therefore there is need for enlightenment for the people of Maluku about real peace. One approach that can be used to enlighten the people of Maluku is through the cultural approach. Generally when talking about a cultural approach, most people refer to local wisdom practiced by the people of Maluku as pela, gandong, lavul ngabal systems and so on, but HMI activists also sought another cultural discourse. According to HMI activists, Maluku society must be enlightened and awakened through the story "patimurah" and the spirit of patriotism for the people of Maluku to rebuild their lives in entirety. Patimurah history is something real and not the result of a historical fact that there is a cultural construct of the political elements. With patimurah historical stories and patriotic zeal, the Maluku people can learn to develop. A word that needs to be underlined is "patriotic spirit". In this context it is universal and can be used to build any terms. Dimensions of a strong desire or a strong will to change life, establish oneself as an individual, group or society as a whole behind the values contained in the statement.

Discourse of peace, security and development has also received attention from GMKI activists in Ambon city, because it becomes a prerequisite for the Maluku community to develop completely. Concentrating on issues of security and peace-building in the context of the city of Ambon, Maluku overall can be also related with the integration of efforts to maintain the Unitary State of the Republic of Indonesia (NKRI). GMKI activists consider that keeping the integrity of the Republic is the absolute responsibility of every citizen, which is done in a simple start to maintain security and order in society, safeguarding of the state assets, guarding against infiltration of ideology that diminish the state ideology of Pancasila, and efforts to disrupt the boundaries of the Unitary State of the Republic of Indonesia/NKRI. 


\section{EDUCATION ISSUES}

The issues of education in the context of Maluku are a matter of concern, as Maluku is categorized as low in terms of the quality of education. Both HMI and GMKI in Ambon view that good education is indispensable for a change in society. In this regard, they recognize that education is becoming a serious concern especially related to knowledge about information technology (IT) among educators, students and the community. It suggests that one of the challenges today and in the future for education in Maluku is related to the use of information technology. The basic problem is the faculty of human resources (teachers) in the IT field is limited, and facilities and infrastructure are not a representation, including the lack of nonformal education facilities outside of school.

Responding to the contexts, HMI conducted IT training in schools with the goal of introducing the world of IT. This is one step in the journey of HMI in response to problems related to the IT world in particular among students and teachers. HMI's involvement in the improvement of IT skills in the school environment is one of the concrete steps of the HMI goals in community service. On the other hand the activity is a socio-religious movement as a manifestation of religious values that are implemented in social action. GMKI views that the educational backwardness in Maluku is related to elements of teaching staff (teachers) in accordance with the competence fields of study as well as a library and its facilities in particular in rural areas, due to lack of government attention to the problems of education. The achievement of the purpose of education is not limited to the eradication of illiteracy in the community, but public education is expected to change lives for the better. So far, it has not been seen in the implementation of the education policy in Maluku.

Against all odds, GMKI is trying to do some concrete measures by plunging into the village performing daily teaching activities, as well as building a public library. GMKI has shown concern to the community that GMKI not only is synonymous with the demonstration, but it also has social sensitivity and responsiveness to social problems. On the other hand, it is a criticism of the government on the functioning and role of government as a representation of the state on one hand that serves the nation, living on the terms of the mandate of the 
constitution, and on the other hand fulfilling the rights of the public through education which is also mandated in the constitution.

\section{CONCLUSION}

The description above has pointed out to the following conclusions: first, cadres or members of HMI and GMKI always strive to dominate public spaces on campus through the distribution of their cadres to occupy strategic positions in the body of executive branches or the student senate, even those seniors who are lecturers have structural positions on campus, which in turn can affect campus policies. Second, the activities in the movement of HMI and GMKI have similarities in terms of responding to societal issues, by paying attention to several aspects including socio-religious issues, local political issues and development of post-conflict society.

In the context of Ambon City which is building itself after the 19992002 conflict, and continuing to experience the dynamics up to now, the social movements of students who view extra-campus organizations to be important in terms of performing the functions of community control over the entire development process in a broad sense. On the contrary, there is another phenomenon that is indisputable which is the strengthening of the construction of religious identity in the public sphere on campus, whereas if not managed properly may have an impact on the formation of understanding of the the exclusive religion that is at the root of radicalism, which has the potential to trigger conflict in Ambon and Maluku overall which is striving to progress out of devastation in the wake of the bloodshed a few years ago.

\section{REFERENCES}

Ahmed, Akbar S. (2003). Islam Sebagai Tertuduh. Bandung: Arasy Mizan.

Andries, Flavius Floris. (2012). Gerakan Masjid Kampus UGM dan UIN Sunan Kalijaga Dalam memahami Politik Nasional. in Jurnal Analisa. P: 137-145.

Appleby, R. Scott. (2000). The Ambivalence of the Sacred: Religion, Violence, and Reconciliation. Lanham, MD: Rowman and Littlefield.

Azra, Azyumardi. (1996). Pergolakan Politik Islam: dari Fundamnetalisme, Modernisme hingga Postmodernisme. Jakarta: Paramadina. 
Burhanuddin, N. (2016). Akar dan Motif Fundamentalisme Islam:Reformulasi Tipologi Fundamentalisme dan Prospeknya di Indonesia. Wawasan: Jurnal Ilmiah Agama Dan Sosial Budaya, 1(2), 199-210. doi: http://dx. doi.org/10.15575/jw.v1i2.831

Baum, Gregory. (2001). Religion and Alienation: A Theological Reading of Sociology. New York: Orbis Books.

Berger, Peter. (1991). Langit Suci, Agama Sebagai Realitas Sosial. Jakarta: LP3ES.

Bourdieu, P. (1977). Outline of A Theory of Practice. Cambridge: Cambridge University Press.

Burrel, R. (1995). Pendahuluan: Fundamnetalisme Islam di Timur tengah: penelitian tentang Asal usul dan keanekaragamannya. in R.M Burrel. Fundamentalisme Islam. Yogyakarta: Pustaka Pelajar.

Choueri, Youssef M. (1997). Islamic Fundamnetalism. London: Books Ens Ltd. Royston Hert.

Ernas, S. (2016). Architecture of Peace in Ambon: Reading Dynamics of Peace After Ten Years of Conflict. Al-Albab, 5(2), 217 - 233. Retrieved from http://jurnaliainpontianak.or.id/index.php/alalbab/article/view/504

Giddens, Anthony. (2003). The Constitution of Society. London: Sage Publication.

Karyono, Ribut. (2003). Fundamentalisme Dalam Islam-Kristen. Yogyakarta: Kalika.

Prasojo, Z.H. (2016). Social Change and the Contributions of the Tionghoa, Dayak and Melayu (Tidayu) in West Kalimantan. In Victor T. King, Zawawi Ibrahim \&Noor Hasharina Hassan (Eds.). Borneo Studies in History, Society and Culture. Singapore: Springer. P: 427-442.

Roy, Oliver. (2005). Genealogi Islam Radikal. Yogyakarta: Genta Press.

Sivan, Emmanuel. (1985). Radical Islam: Medieval Theology and Modern Politics. New Haven: Yale University Press.

Tibi, Bassan. (1988). The Chalenge of Fundamentalism: Political Islam and the New World Disorder. Barkeley: University of California Press.

Turmudi, Endang \& Riza Sihbudi. (2005). Islam dan Radikalisme di Indonesia Jakarta: LIPI Press.

Rumahuru, Y.Z. (2013). Fenomena Gerakan Keagamaan Mahasiswa di Kota Ambon dan Relasinya Dengan Konstruksi Identitas Agama di Kampus: Studi Kasus di Kampus Unptti, IAIN Ambon dan STAKPN Ambon. (Unpublished paper). STAKPN Ambon. 